\title{
Talampicillin: a new derivative of ampicillin
}

\author{
D A LEIGH, D S REEVES, KATE SIMMONS, A L THOMAS, P J WILKINSON
}

British Medical fournal, 1976, 1, 1378-1380

\begin{abstract}
Summary
Talampicillin is a thiazolide carboxylic ester of ampicillin and is hydrolysed in the intestinal mucosa to release free ampicillin. The mean peak serum concentration of ampicillin occurred one hour after a dose of talampicillin and was about twice that attained by an equivalent dose of ampicillin. The presence of food in the stomach reduced and delayed the peak blood levels but did not affect the total amount of antibiotic absorbed or the urinary recovery. Talampicillin had less effect on the faecal flora in volunteers than ampicillin, and no overgrowth with Candida spp or Staphylococcus aureus was seen. Thirty-eight out of 47 urinary infections were eradicated by a seven-day course of talampicillin.
\end{abstract}

\section{Introduction}

Since its introduction in 1964 ampicillin has successfully treated many types of bacterial infection, but gastrointestinal side effects have been reported in up to $20 \%$ of patients. ${ }^{1}$. The phthalidyl thiazolidine carboxylic ester of ampicillin, talampicillin (Talpen, Beecham), has been introduced recently to improve absorption and to reduce these side effects. After oral administration talampicillin is rapidly absorbed and hydrolysed by tissue esterases in the intestinal wall to release into the circulation ampicillin and the ester moiety, mainly 2-hydroxymethyl-benzoic acid. No unchanged talampicillin is detectable in the peripheral blood. ${ }^{2}$ In common with other thiazolidine esters of pencillins ${ }^{3}$ talampicillin has no intrinsic antibacterial activity and should have no direct effect on the bacterial flora of the intestinal tract.

We compare here some pharmacological properties of talampicillin with those of ampicillin and report the effects of oral administration of each drug on the faecal bacterial flora. We also performed a clinical trial of talampicillin in urinary infections at two centres (Wycombe General Hospital and Southmead Hospital).

\section{Methods \\ PHARMACOLOGICAL STUDIES}

The serum and urine concentrations resulting from a single $390-\mathrm{mg}$ dose of talampicillin* were determined in 10 healthy fasting volunteers. Samples of blood were taken 30 minutes and one, two, four, and six hours after the dose, and urine was collected for four two-hour periods.

The effect of food on absorption was determined by a crossover study in which four volunteers took $500 \mathrm{mg}$ of talampicillin or

*Ratio equivalent of talampicillin to ampicillin 1.5:1.

Wycombe General Hospital, High Wycombe, Bucks HP11 2TT

D A LEIGH, MB, BS, consultant microbiologist

KATE SIMMONS, AMILS, research technician

Southmead General Hospital, Bristol BS10 5NB

D S REEVES, MB, MRCPATH, consultant microbiologist

A L THOMAS, MB, MRCP, research registrar (now registrar in renal medicine, Cardiff Royal Infirmary, Cardiff CF2 1SZ)

P J WILKINSON, MB, BCHIR, senior registrar in medical microbiology ampicillin either after an overnight fast, or within 45 minutes of a standard breakfast. Serum levels were measured one, two, four, six, and eight hours after the dose and all urine was collected for two consecutive six-hour periods and the subsequent 12-hour period.

Thirteen patients treated with $750 \mathrm{mg}$ of talampicillin twice daily had serum concentrations monitored after their first dose, which was variably related to their last meal. Most patients in the clinical trial (see below) had urinary concentrations and total recoveries measured for the first 48 hours of treatment. In all studies ampicillin was assayed by a plate diffusion method using the Oxford staphylococcus (NCTC 6571) (at High Wycombe) or Bacillus subtilis (NCTC 6633) (at Bristol) as the indicator strain.

\section{FAECAL FLORA STUDY}

Ten healthy volunteers took $250 \mathrm{mg}$ of talampicillin four times a day for two days. Specimens of faeces collected into containers under liquid paraffin on the day before starting and the day of stopping treatment were examined within 30 minutes. Ten days later the procedure was repeated with the same dose of ampicillin. After each treatment the volunteers were asked about the effect of the antibiotic and the occurrence of any side effects.

The faeces were cultured to determine the total counts of aerobic and anaerobic organisms, and the counts of Candida spp and Staphylococcus aureus. A standard volume of faeces, roughly equivalent to $1 \mathrm{~g}$ weight, was disintegrated in $5 \mathrm{ml}$ of Brewer's broth. Serial hundredfold dilutions were made in Brewer's broth, and surface viable counts from $0 \cdot 1-\mathrm{ml}$ inocula were carried out on blood, MacConkey, salt mannitol, and a selective yeast agar, all incubated aerobically. They were also inoculated on to blood agar containing vitamin $\mathrm{K}$ and haemin, with or without neomycin $(0 \cdot 1 \mathrm{~g} / \mathrm{l})$, and incubated anaerobically by the Gaspak method. Colonies were counted after one and two days' incubation and speciated by routine laboratory methods.

\section{CLINICAL TRIAL}

Forty-seven patients with urinary infection were treated with talampicillin for seven days at a dosage of $390 \mathrm{mg}$ three times daily (at Wycombe) or $750 \mathrm{mg}$ twice daily (at Southmead). Infection was confirmed by a pure growth $>10^{5}$ organisms $/ \mathrm{ml}$ of a single species in two consecutive urinary cultures. All isolates were sensitive to ampicillin on initial laboratory disc testing. Further specimens were examined at one and three or five weeks after stopping treatment. Reinfection was distinguished from failure of eradication by antigenic typing where appropriate (Esch coli) and Dienes' typing (Proteus spp).

The patients gave informed consent; those with a history of penicillin allergy or renal or hepatic insufficiency were not included. All patients were interviewed about the occurrence of side effects, and haematological and biochemical indices were measured before and after treatment.

\section{Resuilts}

SERUM AND URINE CONCENTRATIONS

The mean peak ampicillin concentration of $5.4 \mathrm{mg} / \mathrm{l}$ in the serum of the 10 fasting volunteers occurred one hour after the $390 \mathrm{mg}$ dose of talampicillin (fig 1). Appreciable concentrations were present at 30 minutes and six hours. In 13 inpatients who received $750 \mathrm{mg}$ of talampicillin the mean peak concentration at one hour was $9.4 \mathrm{mg} / \mathrm{l}$ (fig 1), though individual results were more scattered than among the volunteers.

In the crossover study peak serum concentrations of ampicillin were more than twice as high after talampicillin than after ampicillin (fig 2). The mean peak (fasting) level was $5.2 \mathrm{mg} / 1$ after $500 \mathrm{mg}$ of talampicillin and $2.7 \mathrm{mg} / 1$ after the same dose of ampicillin. Food in the stomach delayed the peak but did not affect urinary recoveries of 


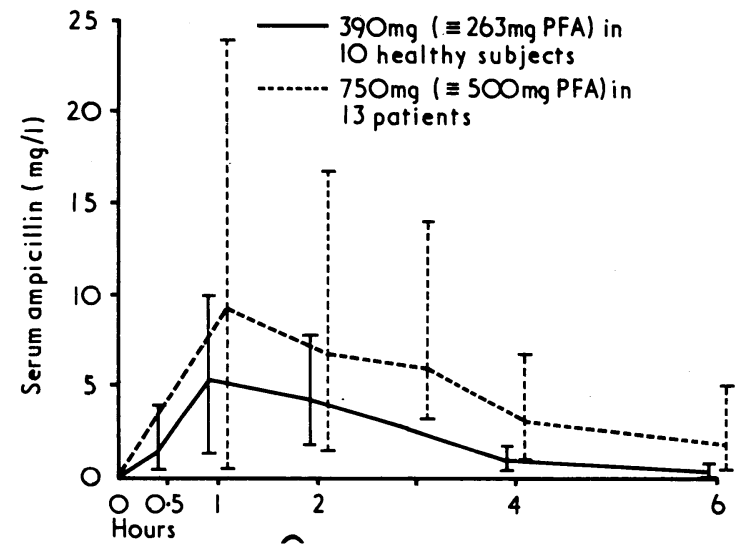

FIG 1-Mean serum concentrations and ranges of ampicillin after single doses of talampicillin in volunteers and patients. PFA $=$ Pure free acid.
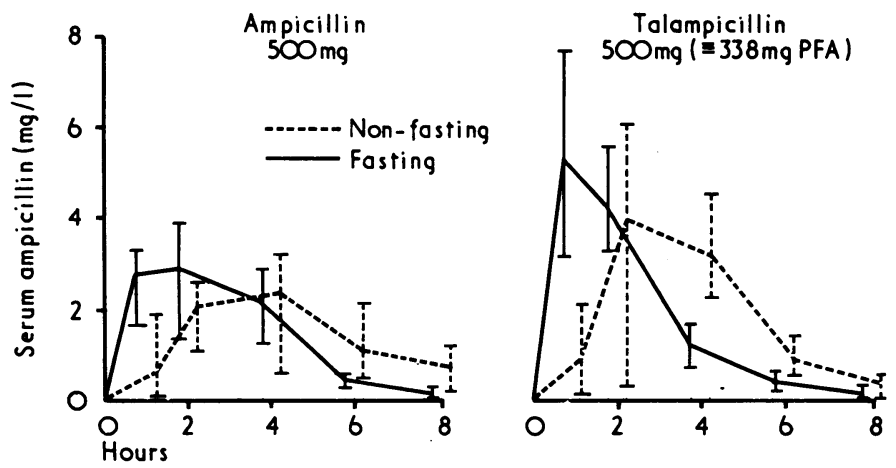

FIG 2-Mean serum ampicillin concentrations and ranges in four healthy subjects after single oral dose of ampicillin or talampicillin. PFA $=$ Pure free acid.

ampicillin (fig 3), which were 52\% (fasting) and 59\% (after food) after talampicillin and $26 \%$ (fasting) and $23 \%$ (after food) after ampicillin.

Urine concentrations of ampicillin in the 10 fasting volunteers were high with a mean peak of $800 \mathrm{mg} / \mathrm{l}$ (range 200-1500) in the first two hours of collection. Altogether $47 \%$ of the administered dose was recovered in six hours. The mean total antibiotic recovery in 40 patients in the trial was $42 \%$ (range $9-79 \%$ ) and showed greater variation than in either of the volunteer groups. The mean urinary ampicillin concentration in the patients was $286 \mathrm{mg} / 1$ (range $67-1026 \mathrm{mg} / \mathrm{l}$ ).

\section{FAECAL FLORA STUDY}

The results of culture of the pretreatment faecal specimens before both talampicillin and ampicillin in the 10 volunteers were similar, and in the four groups of bacteria studied the counts were within $1 \mathrm{log}$ difference for each volunteer. Overall, the total anaerobic counts were between $10^{9}$ and $10^{11}$ organisms per gram of faeces, but the total aerobic counts showed more individual variation, six volunteers having counts of $10^{4}$ to $10^{6}$ organisms per gram of faeces, but four having consistently lower counts of about $5 \times 10^{3}$ organisms. The Candida counts were always below $5 \times 10^{3}$ before treatment, but with Staph aureus there was a range of $5 \times 10^{3}$ to $10^{5}$ organisms.

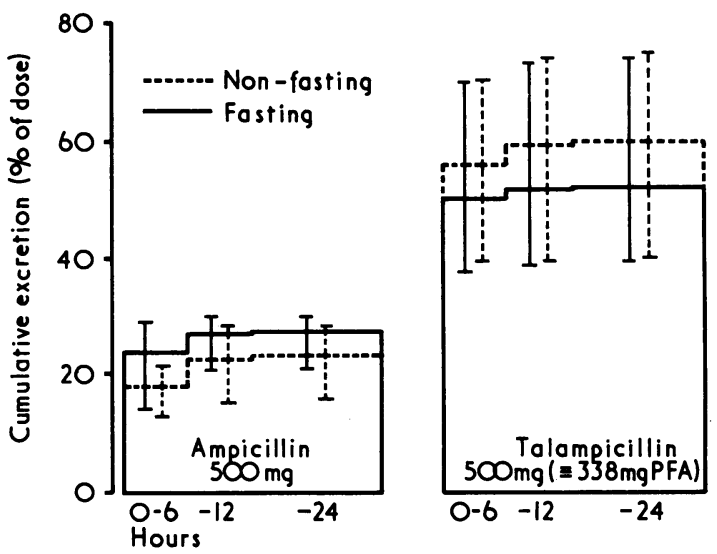

FIG 3-Mean cumulative urinary excretion and ranges of ampicillin in four healthy subjects after single oral dose of ampicillin or talampicillin. PFA = Pure free acid.

Four of the volunteers taking talampicillin showed little change in the counts of the four groups of bacteria (table I). Five showed a considerable increase in total aerobic counts (in four cases due to the presence of ampicillin-resistant strains of Enterobacteriaceae) and two had a reduction in total anaerobic counts.

With ampicillin the changes were more striking. The bacterial counts in eight volunteers changed considerably (table I); in three the total aerobe count increased owing to resistant strains of Enterobacteriaceae, and in four the total Candida count rose considerably. The total anaerobe count fell in four volunteers, one of whom developed

ABLE I-Changes in faecal bacterial flora in volunteers on talampicillin and ampicillin treatment. Results are bacterial counts per gram of faeces

\begin{tabular}{|c|c|c|c|c|c|c|}
\hline \multirow[b]{2}{*}{$\begin{array}{l}\text { Case } \\
\text { No }\end{array}$} & \multirow[b]{2}{*}{ Diarrhoea } & \multicolumn{2}{|c|}{ Pretreatment } & \multicolumn{2}{|c|}{ Post-treatment } & \multirow[b]{2}{*}{ Significant changes } \\
\hline & & $\begin{array}{c}\text { Total } \\
\text { aerobes } \\
\text { (TA) }\end{array}$ & $\begin{array}{c}\text { Total } \\
\text { anaerobes } \\
\text { (TAn) }\end{array}$ & $\begin{array}{c}\text { Total } \\
\text { aerobes } \\
\text { (TA) }\end{array}$ & $\begin{array}{c}\text { Total } \\
\text { anaerobes } \\
\text { (TAn) }\end{array}$ & \\
\hline \multicolumn{7}{|c|}{ Talampicillin } \\
\hline $\begin{array}{r}1 \\
2 \\
3 \\
4 \\
5 \\
6 \\
7 \\
8 \\
9 \\
10\end{array}$ & $\begin{array}{l}\text { None } \\
\text { None } \\
1 \text { day } \\
3 \text { days } \\
\text { None } \\
\text { None } \\
\text { None } \\
\text { None } \\
\text { None } \\
\text { None }\end{array}$ & $\begin{aligned} 3 & \times 10^{6} \\
5 & \times 10^{5} \\
<5 & \times 10^{3} \\
<5 & \times 10^{3} \\
<5 & \times 10^{3} \\
6 & \times 10^{5} \\
<5 & \times 10^{3} \\
4 & \times 10^{6} \\
5 & \times 10^{5} \\
3 & \times 10^{5}\end{aligned}$ & $\begin{array}{l}1.5 \times 10^{10} \\
6 \times 10^{8} \\
10^{10} \times 10^{11} \\
5 \times 10^{11} \\
1.5 \times 10^{11} \\
10^{11} \times 10^{10} \\
2 \times 10^{10} \\
2.5 \times 10^{10} \\
7.5 \times 10^{10} \\
1.5 \times 10^{9}\end{array}$ & $\begin{array}{l}\text { NC } \\
\text { NC } \\
2 \times 10^{8} \\
10^{9} \\
\text { NC } \\
\text { NC } \\
3 \times 10^{11} \\
1 \cdot 5 \times 10^{11} \\
3 \cdot 5 \times 10^{10} \\
\text { NC }\end{array}$ & $\begin{array}{l}\text { NC } \\
2.5 \times 10^{4} \\
\text { NC } \\
<\times 10^{3} \\
\text { NC } \\
\text { NC } \\
\text { NC } \\
\text { NC } \\
\text { NC } \\
\text { NC }\end{array}$ & $\begin{array}{l}\text { None } \\
\text { TAn decreased by } 10^{4} \text {, } \\
\text { TA increased by }>10^{5 *} \\
\text { TA increased by }>10^{5} \text {, TAn decreased by } 10^{8} \\
\text { None } \\
\text { None } \\
\text { TA increased by }>10^{7 *} \\
\text { TA increased by } 10^{5 *} \\
\text { TA increased by } 10^{5 *} \\
\text { None }\end{array}$ \\
\hline \multicolumn{7}{|c|}{ Ampicillin } \\
\hline $\begin{array}{l}1 \\
2 \\
3 \\
4 \\
5 \\
6 \\
7 \\
8\end{array}$ & $\begin{array}{l}\text { None } \\
\text { None } \\
2 \text { days } \\
4 \text { days } \\
1 \text { day } \\
1 \text { day } \\
\text { None } \\
1 \text { day }\end{array}$ & $\begin{array}{r}3 \times 10^{5} \\
2 \cdot 5 \times 10^{5} \\
<5 \times 10^{3} \\
<5 \times 10^{3} \\
<5 \times 10^{3} \\
1.5 \times 10^{5} \\
<5 \times 10^{3} \\
2 \times 10^{5}\end{array}$ & $\begin{array}{l}10^{11} \\
10^{9} \\
2 \times 10^{11} \\
4.5 \times 10^{9} \\
5.5 \times 10^{8} \\
4.5 \times 10^{10} \\
3 \times 10^{11} \\
2.5 \times 10^{11}\end{array}$ & $\begin{array}{l}\text { NC } \\
\text { NC } \\
\text { NC } \\
\text { NC } \\
\text { NC } \\
\text { NC } \\
2 \times 10^{11} \\
\text { NC }\end{array}$ & $\begin{array}{l}\mathrm{NC} \\
<5 \times 10^{3} \\
<5 \times 10^{3} \\
4 \times 5 \times 10^{4} \\
\mathrm{NC} \\
\mathrm{NC} \\
\mathrm{NC} \\
2 \times 10^{8}\end{array}$ & $\begin{array}{l}\text { None } \\
\text { Candida increased by } 10^{3} \text { to } 1.5 \times 10^{8} \text {, TAn decreased by }>10^{5} \\
\text { Candida increased by } 10^{2} \text { to } 2 \times 10^{5} \text {, TAn decreased by }>10^{7} \\
\text { Candida increased by } 10^{2} \text { to } 5 \times 10^{5} \text {, TAn decreased by } 10^{5} \\
\text { Candida increased by } 10^{3} \text { to } 10^{6} \\
\text { None } \\
\text { TA increased by }>10^{7 *} \\
\text { Staph aureus increased by } 10^{3} \text { to } 6.5 \times 10^{6} \text {, TAn decreased by } \\
10^{5}\end{array}$ \\
\hline $\begin{array}{r}9 \\
10\end{array}$ & $\begin{array}{l}\text { None } \\
\text { None }\end{array}$ & $\begin{array}{r}4.5 \times 10^{4} \\
3 \times 10^{5}\end{array}$ & $\begin{array}{l}1.5 \times 10^{10} \\
3 \times 10^{9}\end{array}$ & $\begin{array}{l}5 \times 10^{9} \\
5 \times 10^{10}\end{array}$ & $\begin{array}{l}\mathrm{NC} \\
\mathrm{NC}\end{array}$ & $\begin{array}{l}\text { TA increased by } 10^{5 *} \\
\text { TA increased by } 10^{5 *}\end{array}$ \\
\hline
\end{tabular}


a high Staph aureus count. The post-treatment specimens showed little change from the pretreatment specimens in two subjects.

Five volunteers developed mild diarrhoea lasting from one to four days after ampicillin, and two (cases 3 and 4) also developed it on talampicillin, although on talampicillin the diarrhoea was less severe. No other side effects were noted. In three subjects diarrhoea was associated with increases in Candida spp, but an increase in total aerobic count due to ampicillin-resistant strains of Enterobacteriaceae was not usually associated with symptoms. Total anaerobic count was decreased in six subjects, four of whom suffered from diarrhoea and three of whom also showed an increased Candida count. No volunteer free of side effects to ampicillin complained of symptoms when taking talampicillin.

\section{CLINICAL TRIAL}

Thirty-eight $(81 \%)$ of the 47 urinary infections were eradicated including one that was later found to have been complicated by bacteraemia. Table II shows the infecting organisms and underlying pathology in the 38 patients who were cured (12 men, 26 women; mean age 68.6 years (range 25-93)) and in the nine patients in whom treatment failed ( 5 men, 4 women; mean age $64 \cdot 0$ years (range $50-72$ )).

TABLE II-Urinary infections treated with talampicillin

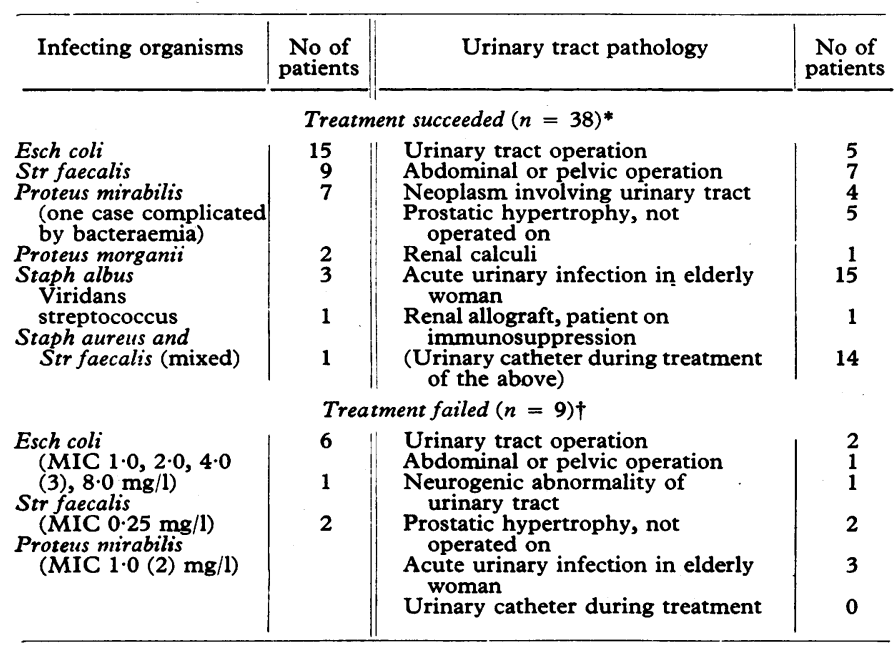

*29 patients given $750 \mathrm{mg}$ of talampicillin twice daily for 7 days, and 9 patients given $390 \mathrm{mg}$ of talampicillin thrice daily for 7 days.

tAll patients given $750 \mathrm{mg}$ of talampicillin twice daily for 7 days.

MIC = Minimum inhibitory concentration.

Few side effects were noted. Four patients complained of a petrollike after-taste, though they continued to accept the drug. A new tablet formulation is believed to reduce these gastric side effects. Vomiting in one patient during treatment was relieved by antiemetics. Three patients developed maculopapular rashes of the type associated with ampicillin. No patient complained of diarrhoea. There were no changes in haematological or biochemical indices that could have been attributed to talampicillin.

\section{Discussion}

Although there is a large range of antibiotics for the treatment of bacterial infections, any new substance that shows either superior absorption or fewer unwanted effects is a valuable addition. Despite its popularity ampicillin has caused a high incidence of gastrointestinal side effects and has occasionally been associated with pseudomembranous colitis. ${ }^{4}$ Talampicillin has been introdured to reduce these problems as it is microbiologically inactive until converted by mucosal cell esterases into ampicillin. Theoretically no effect should be produced on the faecal flora except as a result of the biliary excretion of ampicillin. In a large comparative study of talampicillin and ampicillin $^{6}$ the incidence of diarrhoea was $4.3 \%$ and $8.6 \%$ respectively, a statistically significant difference. Amoxycillin, although bacteriologically active after oral administration, has also been shown to cause fewer cases of diarrhoea than ampicillin, ${ }^{7}$ but a comparative study with talampicillin has not yet been reported, and amoxycillin's effect on faecal flora is not known.

Talampicillin is better absorbed than ampicillin and the mean peak blood level and urinary recovery are more than twice as high as that achieved with an equivalent dose of ampicillin. Food in the stomach reduces and delays the peak blood level after talampicillin to a greater degree than with ampicillin, but the areas under the respective blood level curves with and without food are similar, suggesting that food has no substantial effect on the quantity of free ampicillin recovered from each preparation.

Talampicillin had less effect than ampicillin on the faecal flora of volunteers and caused fewer cases of diarrhoea, although there was no clear correlation between the change in bacterial flora and development of side effects. Side effects were more common when there was an overgrowth of Candida spp, which was seen exclusively with ampicillin. The reduction in total anaerobic count, more commonly seen with ampicillin, may have been due to bacteriologically active concentrations of ampicillin in the faeces, but no assays were carried out. Of the seven volunteers complaining of diarrhoea, however, five showed reductions in total anaerobic count, which suggested an association. Talampicillin was better tolerated than ampicillin in the volunteers and very well tolerated in patients; this may reflect the lack of awareness of this potential side effect by patients and lesser readiness to complain of minor bowel disturbances. Since talampicillin is known to be bacteriologically inert ${ }^{3}$ the changes in faecal flora that occurred in volunteers taking this drug might be explained by the biliary excretion of ampicillin, a view supported by the appearance of ampicillin-resistant strains of Enterobacteriaceae in the faecal flora.

The results of talampicillin treatment of urinary infections, many of which were complicated, were good. Reinfection occurred in nine patients, in each case with an organism resistant to ampicillin-namely Klebsiella (5), Esch coli (1), Proteus sp (2), and Pseudomonas aeruginosa (1). The antibiotic was well tolerated, although three patients developed rashes. The smaller dose of $390 \mathrm{mg}$ of talampicillin three times a day was not particularly associated with failure of treatment, which was probably related to patient factors rather than dose size. A comparative trial against ampicillin in more hospital patients would be necessary to prove conclusively whether talampicillin has equivalent or improved efficacy, but these results, in a generally more difficult group of patients, accord well with those of two large multicentre trials in general practice. ${ }^{6}{ }^{8}$ The clinical use of talampicillin should be associated with a reduction in the incidence of diarrhoea, although, as a penicillin, its use in patients with known hypersensitivity is contraindicated.

\section{References}

1 Tedesco, F J, Digestive Diseases, 1975, 20, 295.

2 Jeffery, D J, Jones, K H, and Langley, P F, Chemotherapy (Proceedings of the IXth International Congress of Chemotherapy), 1975, vol 4, p 237. New York, Plenum, 1976.

${ }^{3}$ Hamilton-Miller, J M, Chemotherapia, 1967, 12, 73.

4 Shapiro, R L, and Newman, A, Radiology, 1973, 108, 263.

${ }^{5}$ Keating, J P, et al, American fournal of Diseases of Children, 1974, 128, 369.

6 Knudsen, E T, and Harding, J W, British fournal of Clinical Practice, 1975, 29, 255.

7 Brogden, R N, Speight, T M, and Avery, G S, Drugs, 1975, 9, 88.

8 Jaffe, G, Murphy, J E, and Robinson, O P W, Practitioner, 1976, 216, 455. 